\title{
CONGESTION, URBAN TRANSPORT, THE FORMAL SECTOR AND INFORMAL ACTORS: KINGSTON, JAMAICA, AND RIO DE JANEIRO, BRAZIL
}

\author{
TERRIANNA O. B. C. SELBY \& CELSO ROMANEL \\ Department of Civil and Environmental Engineering, Pontifical Catholic University of Rio de Janeiro, Brazil
}

\begin{abstract}
The formal sector and informal actors have both been important contributors to public and private urban transport systems in Latin America and the Caribbean. This paper explores key issues around urban transportation, its planning, management and impacts which affect and are affected by both the formal and informal sector. It considers congestion, emission of pollutants and exposure suffered by commuters and communities within influence zones. The Urban Profiles of Kingston (specifically Molynes-Road), Jamaica, and Rio de Janeiro, Brazil (specifically the Lagoa-Barra Highway to the Zuzu Angel Tunnel complex), were compared to assess congestion and emissions. Social costing estimates, as time lost as a result of congestion (expressed as USD/hr), were calculated for both thoroughfares under four speed scenarios, utilizing the free-flow form of the thoroughfares for comparison. This paper covers data and analysis from 2015 to 2018. (This article is part of a longer thesis paper submitted in 2017: Congestion, a Tale of Kingston and Rio de Janeiro: Methods for Understanding and Estimating). Keywords: congestion, informality, informal actors, public transportation, social costing, emissions, exposure, Latin America and Caribbean.
\end{abstract}

\section{INTRODUCTION}

Congestion is hard to define and measure; it presents various challenges to those who work, commute and reside within influence zones of heavily traversed roadways [1]. As a manifestation of inadequate transportation infrastructure, route organisation or policies, congested roadways encourage persons to seek alternatives, behave rashly or remain on roadways and experience repeated exposure to traffic pollutants. Kunzli et al. [2] note that traffic is a major source of both primary particulate matter (PM) emissions and precursors of secondary PM, and substantially contributes to the overall impact of outdoor air pollution.

Road traffic provides one of the major sources of ambient particulate pollution, especially for finer particles. Peak concentrations of atmospheric particles tend to occur close to roads [3]. Urban residents spend considerable amounts of time in traffic environments daily which, as commuters, influences their exposure to numerous pollutants [1], [4]. The longer the exposure in areas where pollutants can build up, the greater the possibility for adverse health effects. As a result, road journeys by car, motorcycles, bicycles and foot make up a large proportion of peak exposure. Pedestrians, small open stalls and businesses on roadsides are under direct exposure to traffic plumes, especially during congestion. Additionally, since ambient emitted ultrafine particles may penetrate into bus cabins, bus commuters are under exposure due to resuspended dust particles in closed vehicle cabins [4]. Concentrations of CO, PM2.5 and PM10 have been shown to be higher on roadways than in subways [4], which is concerning as there is accumulating evidence linking particulate matter exposure to adverse effects on morbidity and cardiovascular mortality [4]-[6].

A better understanding of the causes and effects of congestion is required to better manage the transportation sector in Latin American and Caribbean countries and to curtail any manifestation of adverse health effects and informal actors within the sector [1]. This could be from planning adequate road infrastructure in urban areas to understanding why 
commuters choose certain routes over others and why informal actors are prolific in this sector. Apart from measuring exposure to air pollutants, extrapolating localised emissions and correlating health effects to analyse perceived adverse health effects resulting from urban transportation, there are also methods for social analysis. Social costing can be conducted to quantify the social drawbacks of congestion, a few of which are: the loss of productive time and quality of life; increased fuel consumption, vehicle operation and maintenance costs; incident risk and air pollution and GHG emissions, which are harmful to human health and the environment.

For this study, a modified social costing model is used. It is based on the social model developed by Bilbao-Ubillos [7]. His model is used to measure and value congestion costs on cross-town link roads. The original model considers cost and welfare loss resulting from congestion under two main headings: financial and environmental, with four sub-categories each. Given the difficulties in acquiring environmental data relevant to both study areas (Kingston and Rio de Janeiro), only one component of the methodology, time lost as a result of congestion - $\mathrm{C} 1$ - will be considered.

Kingston in Jamaica, West Indies, and Rio de Janeiro in Brazil, both suffer from the daily effects of congestion. On many roadways, commuters and residents within influence zones and without adequate protection are exposed to air pollution for many hours daily. This includes persons who live, work or study in these areas. Both studied roadways have residences, schools, churches, stores and a market-like structure. Although a broader study on congestion in the two cities can be found in the long paper entitled "Congestion, a Tale of Kingston and Rio de Janeiro: Methods for Understanding and Estimating" [1], the present article provides urban profiles for both cities, examines congestion and public transportation issues and provides a method to estimate social costs according to Bilbao-Ubillos [7].

\section{STUDY AREAS AND APPROACHES}

\subsection{Study areas}

The two study areas were Molynes Road (Fig. 1) in Kingston and St. Andrew Parish located in Jamaica, and the São Conrado-Gávea Highway (Fig. 2(a)), subsection of the Lagoa-Barra Highway (Fig. 2(b)), in the city of Rio de Janeiro (with a focus on the neighbourhoods of Recreio, Barra da Tijuca, São Conrado and Gávea), in the State of Rio de Janiero.

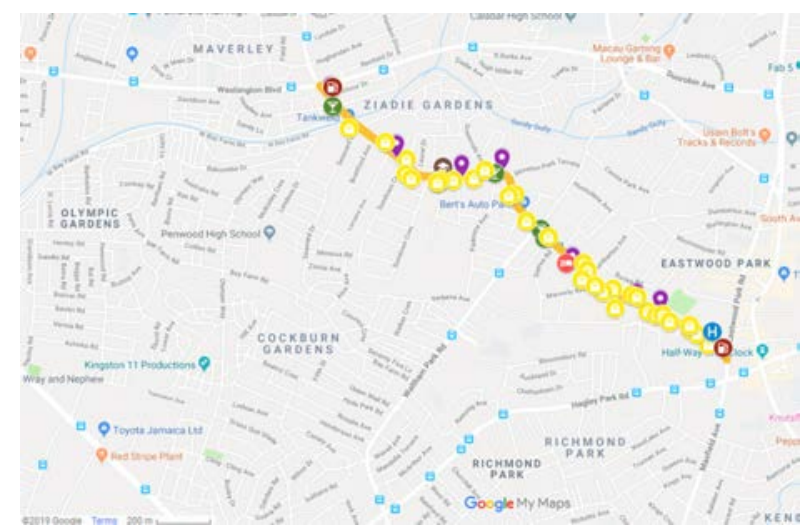

Figure 1: Molynes Road, Kingston - with commercial activities indicated on road. (Source: Selby with Google Maps, 2019.) 


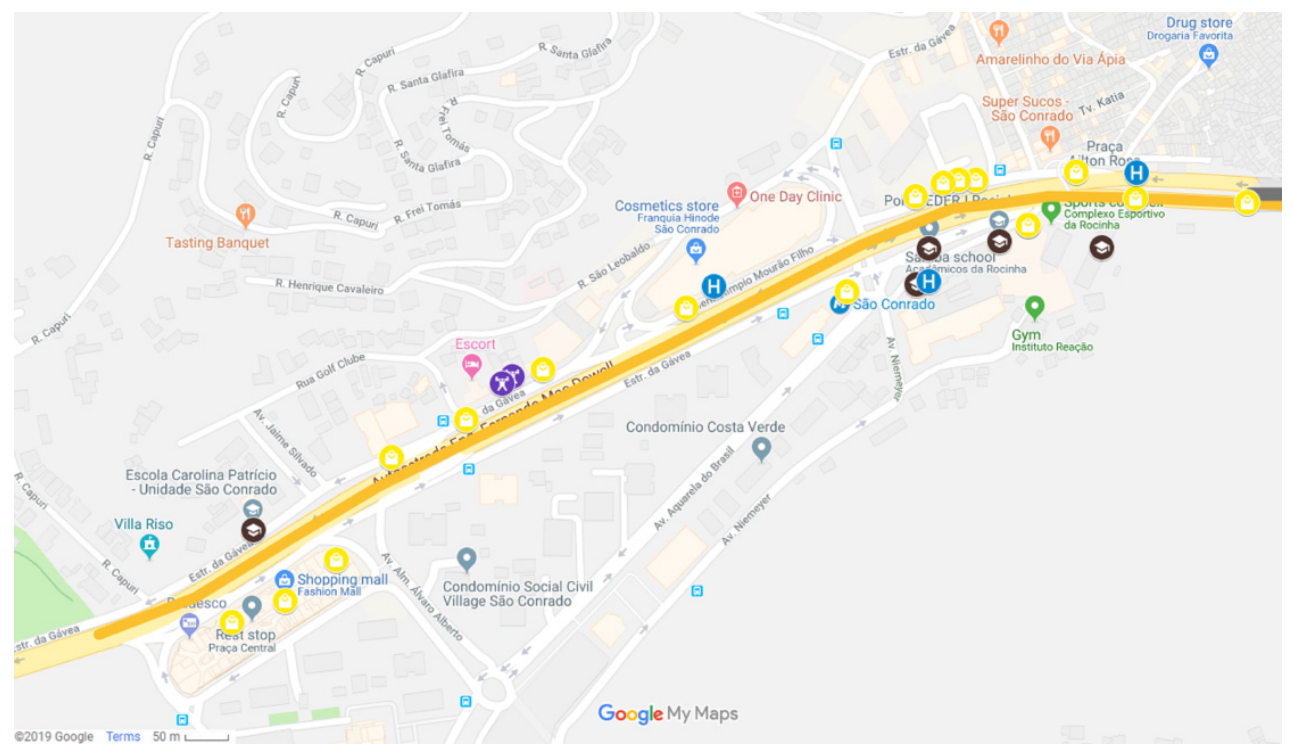

(a)

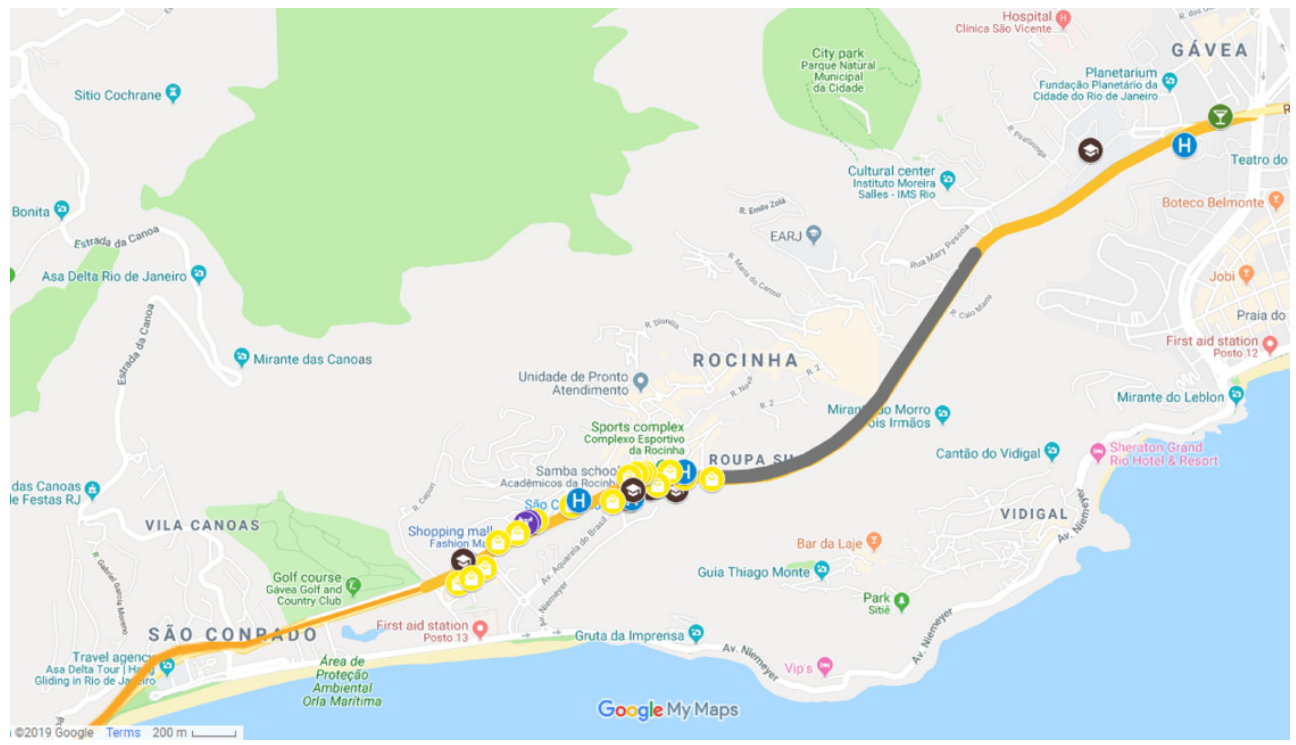

(b)

Figure 2: São Conrado - Gávea with commercial activities indicated on road. (a) Main study area with activities along roadway; (b) Study area including tunnel in grey. (Source: Selby with Google Maps, 2019.)

In order to investigate the current state of the transportation sector and its main actors, it was necessary to create urban profiles of the Kingston, Jamaica and Rio de Janeiro, Brazil. The profiles were based on observation, primary and secondary data. The respective agencies, organizations and companies responsible for providing transportation services in 
both cities were contacted in person, by letter or through their online presence. The rationale of the methodology can be seen in Figs 3 and 4.

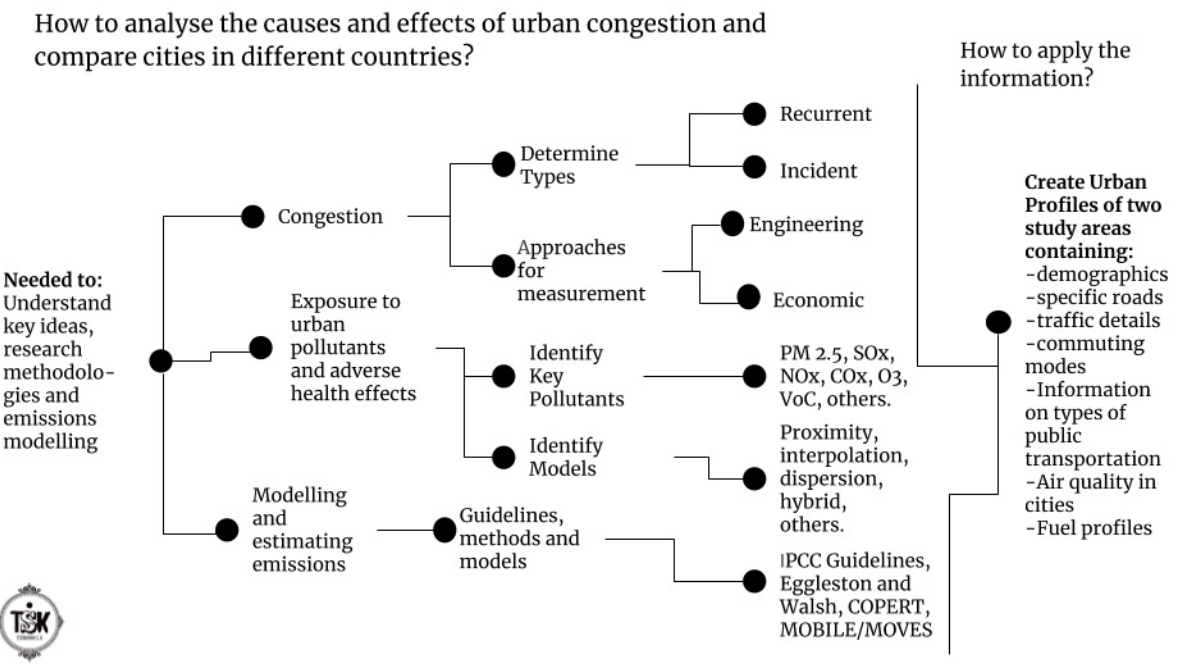

Figure 3: Rationale for study - how to address urban congestion and its effects.

How was data gathered?

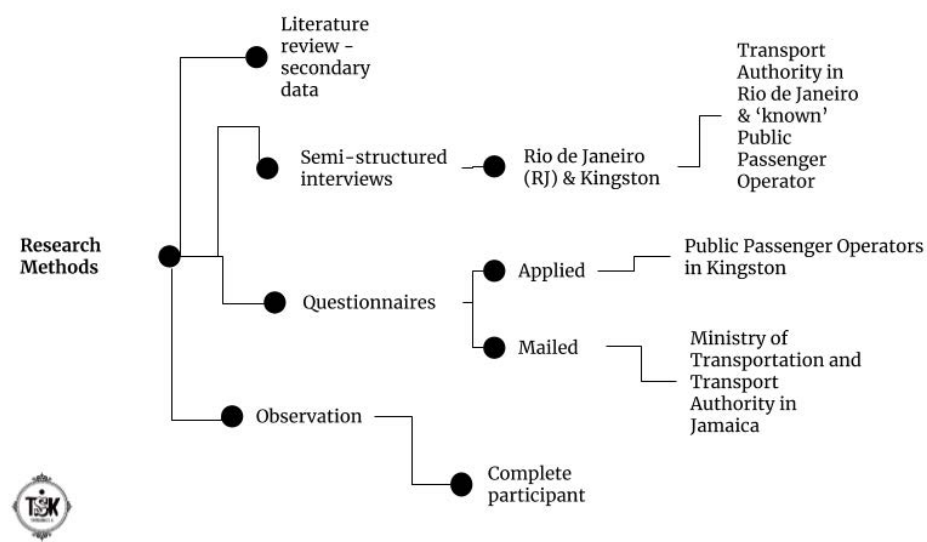

Figure 4: Research methodology - how data was gathered.

Between May and June 2017, questionnaires were applied to twenty-one PPO (public passenger operators) operating within the Washington Boulevard, Half-Way Tree and Barbican areas. Twelve of these questionnaires were applied by the researcher during her one-hour commute from Washington Boulevard to Barbican and nine were applied with focal groups in the second week of June at two gas station gathering points. The fifteen question 
questionnaires focussed on perceptions of congestion and traffic, fuel use, accidents on routes and income.

In 2016 the researcher sent a structured set of questions concerning the transportation sector in Jamaica. It included requests for details on the numbers of vehicles per parish, fuel types, origin of vehicles, numbers of public passenger vehicles and operators, types of licences for road transport, among other details.

In June of 2015, in the city of Rio de Janeiro, the researcher met with one of the lead operations engineers of the Rio Operations Center. Questions asked were focussed on the Zuzu Angel Tunnel, its operations and maintenance, air quality measurements and congestion in relation to the structure. It was highlighted that over five agencies were directly responsible for different aspects of tunnels in the city. Turfism existed between agencies and information was not readily accessible to researchers and the public at large.

With the results of the gathered information the two urban profiles were created (Table 1) and incorporated the following: demographic data, descriptions of the roadways under observation, information on traffic (peaks), commuting modes on the roadways, information on public transportation systems, the "state of the air" (air quality) within the study areas, and the fuel profiles of both cities. Some notable observations originating from the questionnaires applied to public passenger operators that can be seen in Table 2 .

Table 1: Urban profiles of Kingston, Jamaica and Rio de Janeiro (RJ), Brazil.

\begin{tabular}{|c|c|c|}
\hline Categories & \multicolumn{2}{|c|}{ Location and total area of cities } \\
\hline Specific study area & $\begin{array}{l}\text { Kingston and St. } \\
\text { Andrew, Jamaica } \\
\quad\left(480 \mathrm{~km}^{2}\right)\end{array}$ & $\begin{array}{l}\mathrm{RJ} \text { (State), Brazil } \\
\quad\left(1,255 \mathrm{~km}^{2}\right)\end{array}$ \\
\hline City population & 666,041 & 6.32 million \\
\hline Study road & Molynes Road & Lagoa-Barra Highway \\
\hline $\begin{array}{l}\text { Length of road } \\
(\mathrm{km})\end{array}$ & $\begin{array}{c}2.71 \mathrm{~km}-\text { Eastwood } \\
\text { Park Rd }\end{array}$ & $2.87 \mathrm{~km}+1.07 \mathrm{~km}$ \\
\hline $\begin{array}{l}\text { Peak traffic (hourly } \\
\text { range) }\end{array}$ & $\begin{array}{c}7: 30-9: 30 \mid 17: 30- \\
21: 30 \\
\end{array}$ & $6: 30-8: 30 \mid 16: 30-18: 30$ \\
\hline $\begin{array}{l}\text { Public } \\
\text { transportation }(\mathrm{PT}) \\
\text { providers }\end{array}$ & $\begin{array}{l}\text { JUTC, semi-formal } \\
\text { registered vehicles (+ } \\
\text { informal actors) }\end{array}$ & $\begin{array}{c}\text { Intersul, Transcarioca, } \\
\text { Santa Cruz, Bus Rapid } \\
\text { Transit, and Internorte (+ } \\
\text { informal actors) }\end{array}$ \\
\hline $\begin{array}{l}\text { Number of PT } \\
\text { routes }\end{array}$ & 29 (Jamaica) & 96 \\
\hline $\begin{array}{l}\text { Number of } \\
\text { registered motor } \\
\text { vehicles }\end{array}$ & $372,630(2016)$ & $2,699,949(2016)$ \\
\hline $\begin{array}{l}\text { Air monitoring } \\
\text { stations in city }\end{array}$ & 11 & 21 \\
\hline Origin of vehicles & $\begin{array}{c}\text { Japan, S. Korea, UK, } \\
\text { USA }\end{array}$ & $\begin{array}{c}\text { Brazil, USA, Europe, } \\
\text { Asia } \\
\end{array}$ \\
\hline $\begin{array}{l}\text { Average cost of } \\
\text { trip) }\end{array}$ & $\begin{array}{c}100 \mathrm{JMD}(0.77 \mathrm{USD}) \\
-2015\end{array}$ & $\begin{array}{c}3.40 \text { BRL (0.88 USD) - } \\
2015\end{array}$ \\
\hline $\begin{array}{l}\text { Have informal } \\
\text { actors? }\end{array}$ & Yes & Yes \\
\hline
\end{tabular}


Table 2: Noteworthy observations from survey in Kingston, Jamaica.

\begin{tabular}{|c|c|}
\hline \multicolumn{2}{|r|}{ Summarised results from questionnaires and semi-structured interviews } \\
\hline a) & $\begin{array}{l}\text { Many drivers do not own the vehicle they operate. They must pay a daily portion of } \\
\text { their gains to the owner of the vehicle and may be responsible for gas. }\end{array}$ \\
\hline b) & $\begin{array}{l}\text { Reported owners of vehicles may be other drivers, business people, lay-person, } \\
\text { police officers, etc. }\end{array}$ \\
\hline c) & $\begin{array}{l}48 \% \text { of drivers claim to run their routes over } 11 \text { times a day. } 38 \% \text { of drivers operate } \\
\text { in several routes/areas. }\end{array}$ \\
\hline d) & $\begin{array}{l}\text { Most drivers spent between } \$ 5000 \text { and } \$ 7000 \text { JMD to fill their tanks (with some } \\
\text { outliers at } \$ 4000 \text { and } \$ 8000 \text { JMD to fill their tanks. }\end{array}$ \\
\hline e) & Obs: Nissan vehicles seem more economical than Toyotas for operating a taxi \\
\hline f) & edly spent under 40 mins in traffic \\
\hline g) & $\begin{array}{l}\text { Constant Spring Road and Molynes Road, two most congested roadways during } \\
\text { peak hours (Hagley Park Road also mentioned). }\end{array}$ \\
\hline h) & $\begin{array}{l}\text { All drivers had some form of insurance for their vehicles - paying between } \$ 40,000 \\
\text { and over } \$ 300,000 \text { JMD a year }\end{array}$ \\
\hline i) & Most drivers reported seeing about $1-3$ road accidents a week along their routes \\
\hline
\end{tabular}

Social costing, mentioned elsewhere, was calculated based on the model developed by Bilbao-Ubillos [7]. The rationale of the modified version used in the study is found under the social costing heading. Although all components will be listed, only C1 (Table 3) was computed for.

\subsection{Social costing and valuation}

2.2.1 Valuation of time lost as a result of congestion (vehicle delay - $\mathrm{C} 1$ )

This element considers the difference in travel speeds between the expected speed and the average/actual speed observed under congestion. This study uses the difference in states between current congested scenarios and a congestion free alternative. In other words, the same route at free-flow traffic. The monetary equivalent is the price of the time lost as a result of congestion on the road studied, or $\mathrm{C} 1$

$$
(\mathrm{C} 1=\mathrm{W}(\mathrm{D} 1 \times \mathrm{V} 1-\mathrm{D} 2 \times \mathrm{V} 2)),
$$

where $\mathrm{C} 1=$ cost in monetary units of time lost; $\mathrm{D} 1=$ length of current road; $\mathrm{W}=$ current average hourly wage in monetary terms; D2 = average length of proposed alternate route $(\mathrm{km}) ; \mathrm{V} 1=$ observed average speed over the road; V2 = theoretical speed on alternate route $\mathrm{km} / \mathrm{h}$.

2.2.2 Valuation of increased depreciation of vehicles and additional fuel consumption (C2) The element is used to refer to additional costs incurred due to congestion, such as additional fuel, oil consumption, vehicle maintenance and depreciation

$$
(\mathrm{C} 2=\mathrm{P}(\mathrm{D} 1 \times \mathrm{G} 1-\mathrm{D} 2 \times \mathrm{G} 2)),
$$

where $\mathrm{C} 2$ = financial cost from additional fuel consumption; D1 = length of roadway; $\mathrm{D} 2=$ average length of proposed alternate route $(\mathrm{km}) ; \mathrm{P}=$ average price of fuel measured in $\mathrm{USD} / \mathrm{L} ; \mathrm{G} 1$ = average in town fuel consumption of vehicles in $\mathrm{L} / 100 \mathrm{~km} ; \mathrm{G} 2=$ average out-of-town consumption of vehicles in $\mathrm{L} / 10 \mathrm{~km}$. 


\subsubsection{Exposure hours of workers of economic activities along route (estimate) (C3)}

The types of businesses and economic activities to be found along the routes are catalogued and total working hours are estimated. Working hours are then cross-checked with peak traffic times to assess maximum exposure time to traffic pollutants.

2.2.4 Valuation of material damage arising from congestion-related accidents (C4)

The final element identifies specific accidents associated with traffic congestion on cross-town links where the monetary cost of accidents is taken as the result of a valuation of personal injuries and material damage caused

$$
(\mathrm{C} 4=\mathrm{P} \times \mathrm{Vp}+\mathrm{D} \times \mathrm{Vd}),
$$

where $\mathrm{P}=$ number of cases of personal injuries; $\mathrm{D}=$ number of cases of material damages; $\mathrm{Vp}=$ average unitary value of personal injuries; $\mathrm{Vd}=$ unitary value of material damages .

\section{ANALYSIS AND DISCUSSION}

Table 1 contrasts the urban profiles of Kingston, Jamaica and Rio de Janeiro Brazil. It highlights the difference in scale between the two cities, where Rio de Janeiro, state, is four times the size of Jamaica with approximately six times the population of the country. The city of Rio de Janeiro is about three times the size of the Parish of Kingston and St. Andrew, with about nine and half times the population of the Parish.

Within the two urban centres informality is due to the inability, of the government and responsible transportation entities, to meet transportation demands in the respective cities. Route alternatives and reliability are two features which both governments are hard-pressed to provide. This, coupled with a poor understanding of the transportation needs of the population, facilitates the development of the informal transportation sector and the rise of the informal actors. Although there is a resulting loss of revenue by governments and private companies overseeing transportation, commuters are able to move freely about the city and have a certain level of reliability when it comes to transportation access in difficult or remote areas. Additionally, although informal in nature, employment is provided to a number of people who contribute positively to society and eventually pay some form of taxes.

Congestion does not discriminate. It impacts both the formal and informal sectors. Commuters are equally affected by the presence of congestion. Persons who live further away, or in disregarded areas may experience congestion for longer periods than persons who live closer to work, leisure activities or may possess their own vehicles. This differentiation is sometimes ignored in transportation decision-making however, it is critical to social costing and has serious transportation repercussions.

\subsection{Policy and governance}

\subsubsection{Kingston and Rio de Janeiro - 2015-2017}

In Kingston, formal public transportation is provided by the Jamaica Urban Transit Corporation (JUTC) with assistance from other formal and informal actors. In the city of Rio de Janeiro, public transportation is provided by several consortiums. The study area is serviced by five consortiums [8] (Intersul, Transcarioca, Santa Cruz, BRT and Internorte) as well as formal and informal actors. In both cities, fares are set by the government in conjunction with the group or body responsible for the provision of public transportation vehicles. 
There are about eleven bus routes which traverse the study area in Kingston and twenty-one in Rio de Janeiro. Bus fares are around (depending on exchange rates) \$0.77 USD in Kingston and \$0.88 USD in Rio de Janeiro. Rio de Janeiro city has about seven times the amount of vehicles Kingston has on its roadways. Where the majority of vehicles are made in Brazil and some are imported from the USA, Europe and Asia. In Jamaica, the majority of vehicles are imported from Japan, South Korea, the UK and the USA. Both cities rely on the services of formal and informal transportation actors to access remote areas.

\subsubsection{Kingston and Rio de Janeiro - 2018-2019}

During this period Kingston saw no notable changes to the availability of routes, rate of fares or the main actors in the transportation sector. In June of 2018, the public transportation sector of Rio de Janeiro saw an increase in fares across its range of public transportation services (busses, trains, metros, bus rapid transit and light rail vehicles). Bus fares went from about \$0.88 USD in 2015 to about \$1.10 USD in 2018. These measures were taken as part of a deal with the transportation bodies of the city. The measures are an attempt to improve the transparency of their operations and the condition of public transport vehicles. In early 2019 a second readjustment took place keeping the cost of the bus fares around \$1.06/\$1.10 USD (depending on the rate of exchange) [9].

The 2018 arrangement between the government and the providers of public transportation in Rio de Janeiro is interesting because it highlights the blatant issues which existed. Especially issues related to transparency, information disclosure and the needs of commuters. According to O Globo [10] important conditions placed by the government included: having $\mathrm{AC}$ in all vehicles by 2020, access to complete financial reports on number of passengers and profits made, donations to repair heavily damaged roads, among others. Interestingly, in Kingston, data on passengers is also not readily available to government agencies, much less the public.

\subsection{Social costing}

Social costing (Table 3) is an important tool to analyse congestion. It integrates the aforementioned data with human perception of wellness and comfort. The method allows one to place a value to the inconvenience of being delayed as a result of congestion. It makes it possible to consider other costs incurred by additional fuel consumption as well as more subjective measurements such as, dissatisfaction and irritation. Once the data is available, the model is able to estimate and attribute a value to road accidents resulting from congestion.

There were several factors which prevented the collection of the data necessary to calculate all of the items of the social costing method under Bilbao-Ubillos [7]. As a result, only the first item, $\mathrm{C} 1$, was calculated. $\mathrm{C} 1$ sets the foundation for how social costing can quantitatively value urban problems like congestion when considering somewhat subjective inputs. The computed values represent what is lost, on average, per working person, on the congested roadways, travelling at the respective speeds. These bring an interesting perspective to congestion and indicate how costly the problem really is.

\subsubsection{Social costing calculations Kinston and Rio de Janeiro}

Table 3 shows the incurred costs of congestion along the two thoroughfares under study at a maximum speed of $100 \mathrm{Km} / \mathrm{hr}$ and a moderate speed of $60 \mathrm{Km} / \mathrm{hr}$. Observed speeds on roadways varied between 10 to $40 \mathrm{Km} / \mathrm{hr}$, this was an average as stretches of traffic could go below $5 \mathrm{Km} / \mathrm{hr}$. Average hourly wages were based on reported minimum wages for Jamaica (\$3.00 USD/hr USD) and for Rio de Janeiro (\$3.19 USD/hr ). 
Table 3: Social costing $-\mathrm{C} 1-2015-2017$.

\begin{tabular}{|c|c|c|c|c|c|}
\hline \multicolumn{6}{|c|}{ a) The value of the time lost as a result of congestion (vehicle delay) } \\
\hline $\mathrm{C} 1=$ & Considerations & Molynes & Lagoa-Barra & \begin{tabular}{|c|} 
Zuzu Angel \\
Tunnel
\end{tabular} & $\begin{array}{l}\mathrm{RJ}-\text { total } \\
\text { study road }\end{array}$ \\
\hline $\mathrm{W}$ & Average hourly wage & $3.00 \mathrm{USD} / \mathrm{hr}$ & $3.19 \mathrm{USD} / \mathrm{hr}$ & $3.19 \mathrm{USD} / \mathrm{hr}$ & $3.19 \mathrm{USD} / \mathrm{hr}$ \\
\hline \multirow[t]{4}{*}{ V1 } & $\begin{array}{l}\text { Observed average } \\
\text { speed over road }\end{array}$ & $10 \mathrm{~km} / \mathrm{hr}$ & $10 \mathrm{~km} / \mathrm{hr}$ & $10 \mathrm{~km} / \mathrm{hr}$ & $10 \mathrm{~km} / \mathrm{hr}$ \\
\hline & & $20 \mathrm{~km} / \mathrm{hr}$ & $20 \mathrm{~km} / \mathrm{hr}$ & $20 \mathrm{~km} / \mathrm{hr}$ & $20 \mathrm{~km} / \mathrm{hr}$ \\
\hline & & $30 \mathrm{~km} / \mathrm{hr}$ & $30 \mathrm{~km} / \mathrm{hr}$ & $30 \mathrm{~km} / \mathrm{hr}$ & $30 \mathrm{~km} / \mathrm{hr}$ \\
\hline & & $40 \mathrm{~km} / \mathrm{hr}$ & $40 \mathrm{~km} / \mathrm{hr}$ & $40 \mathrm{~km} / \mathrm{hr}$ & $40 \mathrm{~km} / \mathrm{hr}$ \\
\hline D1 & Length of current road & $2.71 \mathrm{~km}$ & $1.07 \mathrm{~km}$ & $2.87 \mathrm{~km}$ & $3.94 \mathrm{~km}$ \\
\hline D2 & $\begin{array}{l}\text { Average length of } \\
\text { proposed alternate road }\end{array}$ & $2.71 \mathrm{~km}$ & $1.07 \mathrm{~km}$ & $2.87 \mathrm{~km}$ & $3.94 \mathrm{~km}$ \\
\hline $\mathrm{V} 2$ & Speed on alternate road & $100 \mathrm{~km} / \mathrm{hr}$ & $100 \mathrm{~km} / \mathrm{hr}$ & $100 \mathrm{~km} / \mathrm{hr}$ & $100 \mathrm{~km} / \mathrm{hr}$ \\
\hline \multicolumn{6}{|c|}{$\mathrm{c} 1=\mathrm{w}(\mathrm{d} 1 \mathrm{xv} 1-\mathrm{d} 2 \mathrm{xv} 2)$} \\
\hline \multirow[t]{5}{*}{$\mathrm{C} 1$} & Location & $10 \mathrm{~km} / \mathrm{hr}$ & $20 \mathrm{~km} / \mathrm{hr}$ & $30 \mathrm{~km} / \mathrm{hr}$ & $40 \mathrm{~km} / \mathrm{hr}$ \\
\hline & Molynes & -731.7 USD & -650.4 USD & -569.1 USD & -487.8 USD \\
\hline & Lagoa-Barra & -307.2 USD & -273.1 USD & -238.9 USD & -204.8 USD \\
\hline & Zuzu Angel & -823.9 USD & -732.4 USD & -640.9 USD & -549.3 USD \\
\hline & RJ - total study road & $-1,131.2$ USD & $-1,005.5$ USD & -879.8 USD & -754.1 USD \\
\hline \multicolumn{6}{|c|}{ b) The value of the time lost as a result of congestion (vehicle delay) } \\
\hline $\mathrm{C} 1=$ & Considerations & Molynes & Lagoa-Barra & \begin{tabular}{|c|} 
Zuzu Angel \\
Tunnel
\end{tabular} & $\begin{array}{l}\mathrm{RJ}-\text { Total } \\
\text { study road }\end{array}$ \\
\hline $\mathrm{W}$ & Average hourly wage & $3.00 \mathrm{USD} / \mathrm{hr}$ & $3.19 \mathrm{USD} / \mathrm{hr}$ & $3.19 \mathrm{USD} / \mathrm{hr}$ & $3.19 \mathrm{USD} / \mathrm{hr}$ \\
\hline \multirow[t]{4}{*}{ V1 } & $\begin{array}{l}\text { Observed average } \\
\text { speed over road }\end{array}$ & $10 \mathrm{~km} / \mathrm{hr}$ & $10 \mathrm{~km} / \mathrm{hr}$ & $10 \mathrm{~km} / \mathrm{hr}$ & $10 \mathrm{~km} / \mathrm{hr}$ \\
\hline & & $20 \mathrm{~km} / \mathrm{hr}$ & $20 \mathrm{~km} / \mathrm{hr}$ & $20 \mathrm{~km} / \mathrm{hr}$ & $20 \mathrm{~km} / \mathrm{hr}$ \\
\hline & & $30 \mathrm{~km} / \mathrm{hr}$ & $30 \mathrm{~km} / \mathrm{hr}$ & $30 \mathrm{~km} / \mathrm{hr}$ & $30 \mathrm{~km} / \mathrm{hr}$ \\
\hline & & $40 \mathrm{~km} / \mathrm{hr}$ & $40 \mathrm{~km} / \mathrm{hr}$ & $40 \mathrm{~km} / \mathrm{hr}$ & $40 \mathrm{~km} / \mathrm{hr}$ \\
\hline D1 & Length of current road & $2.71 \mathrm{~km}$ & $1.07 \mathrm{~km}$ & $2.87 \mathrm{~km}$ & $3.94 \mathrm{~km}$ \\
\hline D2 & $\begin{array}{l}\text { Average length of } \\
\text { proposed alternate road }\end{array}$ & $2.71 \mathrm{~km}$ & $1.07 \mathrm{~km}$ & $2.87 \mathrm{~km}$ & $3.94 \mathrm{~km}$ \\
\hline $\mathrm{V} 2$ & Speed on alternate road & $60 \mathrm{~km} / \mathrm{hr}$ & $60 \mathrm{~km} / \mathrm{hr}$ & $60 \mathrm{~km} / \mathrm{hr}$ & $60 \mathrm{~km} / \mathrm{hr}$ \\
\hline \multicolumn{6}{|c|}{$\mathrm{c} 1=\mathrm{w}(\mathrm{d} 1 \mathrm{xv} 1-\mathrm{d} 2 \mathrm{xv} 2)$} \\
\hline \multirow[t]{5}{*}{$\mathrm{C} 1$} & Location & $10 \mathrm{~km} / \mathrm{hr}$ & $20 \mathrm{~km} / \mathrm{hr}$ & $30 \mathrm{~km} / \mathrm{hr}$ & $40 \mathrm{~km} / \mathrm{hr}$ \\
\hline & Molynes & -406.5 USD & -325.2 USD & -243.9 USD & -162.6 USD \\
\hline & Lagoa-Barra & -170.7 USD & -136.5 USD & -102.4 USD & -68.3 USD \\
\hline & Zuzu Angel & -457.8 USD & -366.2 USD & -274.7 USD & -183.1 USD \\
\hline & RJ - total study road & -628.5 USD & -502.7 USD & -377.1 USD & -251.4 USD \\
\hline
\end{tabular}

RJ: Rio de Janeiro. 
As was expected and can be seen in Table 3, the greatest losses are from the lowest speeds travelled on the roadway. At a maximum free-flow speed of $100 \mathrm{Km} / \mathrm{hr}$, this amounts to a loss of about \$732 USD on Molynes road and about \$1131 USD on the Lagoa-Barra highway under study in Rio. At a maximum speed of $60 \mathrm{Km} / \mathrm{hr}$, the values are still considerable at \$407 USD on Molynes and \$629 USD.

\section{CONCLUSION}

Social costing allows governments, sector actors and the population at large to see what they stand to lose and conversely what they stand to gain by ascribing to better transportation practices. When researched in conjunction with pollution emission values, it provides a holistic view of transportation challenges and offers more avenues for managing issues such as congestion.

Clearly, between the actions of formal and informal actors and the pressing need for adequate transportation in cities, it is fair to wonder whether congestion is a problem that can be solved. Once alternate roadways exist, these routes must be informed to commuters and must be used. This is in order to alleviate pressures on road infrastructure, decrease the amount of concentrated emissions within urban areas and the number of people exposed daily, decrease the amount of time wasted by commuters in traffic, and in so doing, increase overall satisfaction in the transportation sector.

The transportation sector must be routinely studied and analysed, decision-makers must actively engage in travelling routes and getting feedback. All stakeholders must be involved in creating policies for the transportation sector and modifying these when necessary. Once a city is interested in maintaining formal structures and deterring informality (or working with informal actors), there must first be an understanding of what exists, what the problems are, and what can be done.

To better manage informality in the transport sector continuous dialogue between formal agencies and informal actors must exist. Formal actors are seldom able to target all locations, especially those difficult to access because of morphology, politics or violence. However, neighbourhoods rely on services which flow to and from these locations which means that some form of transportation must exist. Government agencies must look into alternate approaches to dealing with informal actors, enlisting them in the provision of safe transportation, and providing them with the necessary assurances so they are willing to be monitored.

Once there is an understanding of the current transportation sector, its actors and the needs of the population, follow-up studies can be done to mitigate transportation challenges. Data is necessary to facilitate studies and decision-making. In formalising, government agencies must become strategic in establishing their own overarching goals and objectives so that they act effectively and record data accurately. Collected data will then allow for the calculations of emissions, estimations of exposure, social costs and allow for informed decision-making.

\section{ACKNOWLEDGEMENT}

I would like to thank everyone who made this study possible, especially those who offered motivation, resources, advice and life.

\section{REFERENCES}

[1] Selby, T.O. \& Romanel, C., Congestion, a Tale of Kingston and Rio de Janeiro: Methods for Understanding and Estimating, Department of Civil Engineering, Pontifical Catholic University of Rio de Janeiro: Rio de Janeiro, 2017. 
[2] Kunzli, N. et. al., Public-health related impact of outdoor and traffic-related air pollution: A European assessment. The Lancet, 356(9232), pp. 795-801.

[3] Borrego, C., Tchepel, O., Costa, A.M., Martins, H., Ferreira, J. \& Miranda, A.I., Traffic-related particulate air pollution exposure in urban areas. Atmospheric Environment: ScienceDirect, 40(37), pp. 7205-7214, 2006.

[4] Yan, C. et al., Commuter exposure to particulate matter and particle-bound PAHs in three transportation modes in Beijing, China. Environmental Pollution, 204, pp. 199-206, 2015.

[5] Wang, M. et al., Long-term exposure to elemental constituents of particulate matter and cardiovascular mortality in 19 European cohorts: Results from the ESCAPE and TRANSPHORM projects. Environment International, 66, pp. 97-106, 2014.

[6] Ali, M.S., Adnan, M., Noman, S.M. \& Baqueri, S.F., Estimation of traffic congestion cost - a case study of a major arterial in Karachi. Procedia Engineering, 77, pp. 37-44, 2014.

[7] Bilbao-Ubillos, J., The cost of urban congestion, estimation of welfare losses arising from congestion on cross-town link roads. Transportation Research Part A: Policy and Practice, 42(8), pp. 1098-1108, 2008.

[8] Consórcios e empresas, Rio Onibus, Online. www.rioonibus.com/o-rioonibus/consorcios-e-empresas/. Accessed on: 13 Dec. 2015. (In Portuguese.)

[9] Aumento na passagem de ônibus entra em vigor no Rio, mas passageiros reclamam das condições do transporte, G1, Online. https://g1.globo.com/rj/rio-dejaneiro/noticia/2019/02/02/aumento-na-passagem-de-onibus-entra-em-vigor-no-riomas-passageiros-reclamam-das-condicoes-do-transporte.ghtml. Accessed on: 3 Apr. 2019. (In Portuguese.)

[10] Tarifa de ônibus aumenta para $\mathrm{R} \$ 3,95$ a partir de domingo, O Globo, Online. oglobo.globo.com/rio/tarifa-de-onibus-aumenta-para-395-partir-de-domingo22775236. Accessed on: 3 Apr. 2019. (In Portuguese.) 